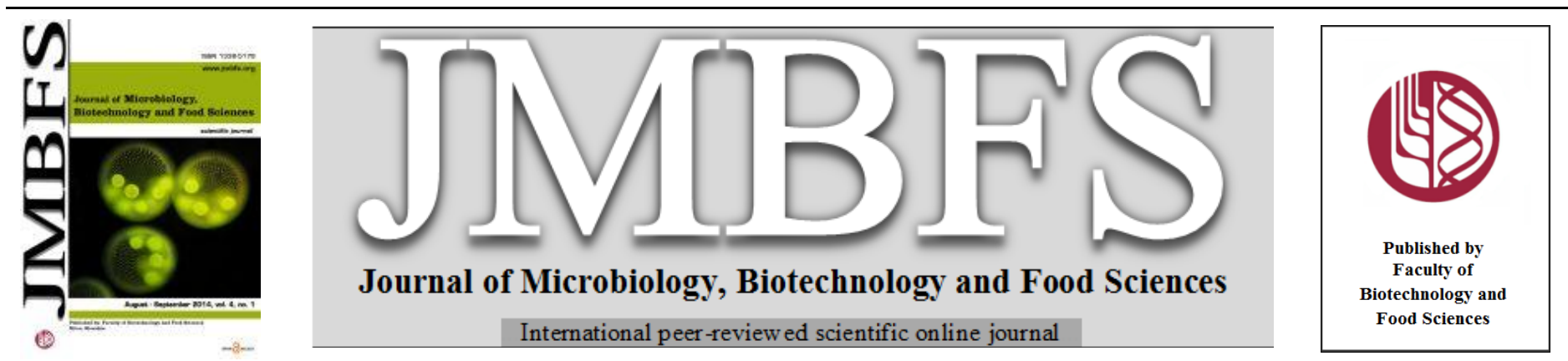

\title{
INVERTASE FROM A CANDIDA STELLATA STRAIN ISOLATED FROM GRAPE: PRODUCTION AND PHYSICO- CHEMICAL CHARACTERIZATION
}

\author{
Cristiane Abe Gargel ${ }^{1}$, Milla Alves Baffi, ${ }^{*}$, Eleni Gomes ${ }^{1}$, Roberto Da-Silva $^{l}$ \\ Address(es): Milla Alves Baffi, \\ ${ }^{1}$ São Paulo State University (Laboratory of Biochemistry and Applied Microbiology, Rua Cristovão Colombo 2265, 15054-000, São José do Rio Preto, SP, Brazil. \\ ${ }^{2}$ Uberlândia Federal University (UFU), Agricultural Sciences Institute (ICIAG), MG, 38405-303, Uberlândia, MG, Brazil.
}

*Corresponding author: millabaffi@yahoo.com.br

doi: 10.15414/jmbfs.2014.4.1.24-28

\section{ARTICLE INFO}

Received 5. 2. 2014

Revised 9. 6. 2014

Accepted 19. 6. 2014

Published 1. 8. 2014

Regular article

OPEN $\partial_{\text {ACCESS }}$

\begin{abstract}
Invertases are enzymes which hydrolyze the sucrose and are widely employed in food and pharmaceutical industries. In this work, the screening of autochthonous grape yeasts from Brazil was carried out in order to investigate their invertase production potential. Yeasts belonging to Saccharomyces, Hanseniaspora, Sporidiobolus, Issatchenkia, Candida, Cryptococcus and Pichia genera were analyzed by submerged fermentation (SbmF) using sucrose as substrate. Among them, Candida stellata strain (N5 strain) was selected as the best producer $(10.6 \mathrm{U} / \mathrm{ml}$ after 48 hours of $\mathrm{SbmF})$. This invertase showed optimal activity at $\mathrm{pH} 3.0$ and $55^{\circ} \mathrm{C}$, demonstrating appropriate characters for application in several industrial processes, which includes high temperatures and acid pHs. In addition, this invertase extract presented tolerance to low concentrations of ethanol, suggesting that it could also be suitable for application at the beginning of alcoholic fermentation. These data provide promising prospects of the use of this new invertase in food and ethanol industry.
\end{abstract}

Keywords: Grape yeasts, non-Saccharomyces, invertase, food industry

\section{INTRODUCTION}

The invertases, also named $\beta$-D-fructofuranosidases (EC 3.2.1.26), are one of the most widely employed enzymes in industries with a wide range of commercial applications including lactic acid production (Acosta et al., 2000); fermentation of sugarcane into ethanol (Lee and Huang, 2000) and fructose syrup production (de Almeida et al., 2005). It is also used in pharmaceutical industry as digestive aid tablets, powder milk for child nutrition as calf feed preparation and assimilation for alcohol in fortified wines (Uma et al., 2012).

Invertases catalyze the hidrolysis of the glicosidic bond from sucrose in its respective monomers glucose and fructose. The product of this hydrolysis, the glucose and fructose syrup, is known as "inverted sugar" and has importan features: it is sweeter than sucrose (about 40\%), it is stable at high concentrations, it is more soluble than the original disaccharide and it has higher boiling and lower freezing points (Uma et al., 2012). As a consequence, the crystallization phenomenon is avoided, improving the texture of candies, jams, ice creams, and other food products (Valerio et al., 2013).

These enzymes can be synthesized by plants (Hussain et al., 2009), some filamentous fungi (Chelliappan and Madhanasundareswari, 2013) and yeasts such as Saccharomyces cerevisae (Pataro et al., 2002), Candida utilis (Belcarz et al., 2002), Rhodotorula glutinis (Rubio et al., 2002) and Pichia fermentans (Caputo et al., 2012), being $S$. cerevisiae the chief strain used for the production of invertases (Kulshrestha et al., 2013).

In yeasts, they are present either as extracellular as well as intracellular forms, being $80 \%$ from extracellular location (Nakano et al., 2000). The secreted invertase is a glycoprotein with around $50 \%$ of carbohydrates, while the intracellular form is composed only by aminoacids. For the production of invertases useful in food industry, extracellular invertases are preferable and more appropriate since they are released directly in the culture broth avoiding additional steps of cell rupture to extract the enzyme (Kulshrestha et al., 2013). In spite of the the majority of the studies concerning yeast invertases has focused on Saccharomyces cerevisiae (Pataro et al. 2002), there are few works describing invertase production by other yeast genera (Turkel et al. 2006) Besides, up to this moment there is not any study reporting authoctonous grape yeasts as invertase producers. Thus, the investigation of new yeast species able to produce such enzymes could be of great importance for different industrial processes.

The objective of our study was the screening of yeast strains isolated from grape surfaces invertase biosynthesis and secretion. The physico-chemical properties from the selected best producer strain were evaluated in order to characterize this new crude enzyme and suggest possible applications in food industries which operate at similar $\mathrm{pH} /$ temperature conditions.

\section{MATERIAL AND METHODS}

Yeasts

Saccharomyces and other yeast strains were obtained from the Grape Yeast Collection (Sao Paulo State University, Brazil) and were previously assigned to species level by analysis of the 5.8S-ITS ribosomal DNA (rDNA) region (Baffi et al., 2011). The stock culture was preserved in YPD agar (1\% yeast extract, $1 \%$ peptone and $2 \%$ glucose $)$ supplemented with choramphenicol $\left(100 \mathrm{mg} \mathrm{l}^{-1}\right)$ ampicillin $\left(25 \mu \mathrm{g} \mathrm{ml}^{-1}\right)$ and sodium propionate $\left(0.25 \mathrm{~g} \mathrm{l}^{-1}\right)$ at room temperature. A total of 34 yeast strains was screened for invertase production and compared to a Saccharomyces cerevisae commercial strain. Yeast strains are listed in Table 1.

\section{Invertase production by SbmF}

An isolated colony from each yeast strain was pre-grown in YPD medium overnight at $28-30^{\circ} \mathrm{C}$ under shaking. The submerged fermentation (SbmF) was carried out under aerobic conditions, using a $18 \mathrm{~h}$-old culture with an initial inoculum concentration of $1.0 \times 10^{6} \mathrm{CFU} \mathrm{ml}^{-1}$, in erlenmeyer flasks containing 50 $\mathrm{ml}$ of liquid YP media, with $2 \%$ sucrose (Shafic et al., 2003, with modifications) Cultures were incubated for $120 \mathrm{~h}$ at $28{ }^{\circ} \mathrm{C}$ and $200 \mathrm{rpm}$. To ascertain the time of the peak enzyme synthesis, aliquots were withdrawn and the invertase activity was determined at time intervals of $24 \mathrm{~h}$. Samples were centrifuged at 12,000 g for $15 \mathrm{~min}$ at $5^{\circ} \mathrm{C}$. Afterwards, the supernatant was discarded and the precipitate was washed with $\mathrm{NaCl} 0.8 \%$ solution for $15 \mathrm{~min}$ and submitted to centrifugation at the same conditions described above. Afterwards, the cells were suspended in $5 \mathrm{ml}$ of $0.2 \mathrm{~mol} \mathrm{l}^{-1}$ sodium acetate buffer and macerated with washed sand. Finally, it was centrifuged again for $10 \mathrm{~min}$ and the enzymatic extract was filtrated in a Millipore membrane. 
Table 1 Yeast species and respective strains screened for invertase production

\begin{tabular}{ll}
\hline Yeast species & Strains \\
\hline Hanseniaspora uvarum & $\mathrm{U} 6, \mathrm{U} 17, \mathrm{~N} 1, \mathrm{~N} 7, \mathrm{~N} 36,10 \mathrm{~A}, 3 \mathrm{~A}$ \\
Saccharomyces cerevisae & $\mathrm{N} 24, \mathrm{~N} 37, \mathrm{~N} 38,3$ \\
Candida quercitrusa & $\mathrm{N} 17, \mathrm{~N} 19$ \\
Pichia orientalis & $\mathrm{N} 40,52,18,28$ \\
Pichia kluyveri & $\mathrm{N} 31$ \\
Pichia terricola & $22 \mathrm{~A}, 5 \mathrm{~A}$ \\
Pichia occidentalis & $39,41,43$ \\
Sporidiobolus pararoseus & $8 \mathrm{~A}$ \\
Candida stellata & $\mathrm{N} 5, \mathrm{~N} 9$ \\
Aureobasidium pullulans & $1 \mathrm{~A}, 4 \mathrm{~A}, 12 \mathrm{~A}$ \\
Cryptococcus laurenti & $\mathrm{U} 2$ \\
Cryptococcus flavescens & $\mathrm{U} 8, \mathrm{U} 10$ \\
Meyerozyma quilliermondii & $\mathrm{U} 5, \mathrm{U} 9$ \\
\hline
\end{tabular}

\section{Cellular growth and $\mathrm{pH}$ analysis}

The cell viability was monitored at fermentation medium, at intervals of $24 \mathrm{~h}$, by counting of viable cells in a Neubauer chamber after differential staining using Erythrosine B (ERB) (Karwoski et al., 1995). The acidity of the fermentation media was also monitored by measuring the $\mathrm{pH}$ value at intervals of $24 \mathrm{~h}$. These data were compared with the ones obtained with a commercial S. cerevisiae strain.

\section{Invertase activity assay}

The assay mixture consisted of $0.2 \mathrm{ml}$ of $0.5 \mathrm{~mol}^{-1}$ sucrose, $0.6 \mathrm{ml}$ of sodium acetate buffer $\left(0.2 \mathrm{~mol} \mathrm{l}^{-1}\right.$, pH 5.0) and $0.2 \mathrm{ml}$ of the enzymatic extract. The mixture was incubated at $37^{\circ} \mathrm{C}$ for $30 \mathrm{~min}$. The amount of reducing sugars released was determined spectrophotometrically at $546 \mathrm{~nm}$ using the 3.5 dinitrosalicylic acid (DNS) method (Miller, 1959). Enzyme activity was expressed in $\mathrm{U} \mathrm{ml}^{-1}$. One unit (U) of enzymatic activity was defined as the amount of enzyme that releases $1 \mu$ mole of glucose/fructose from sucrose per minute under the conditions of the assay. Assays were conducted in duplicate.

\section{Physico-chemical characterization}

Optimum $\mathrm{pH}$ was determined by measuring the invertase activity over a $\mathrm{pH}$ range of $2.0-8.0$ at $37^{\circ} \mathrm{C}$, in citrate phosphate buffer $(100 \mathrm{mM}-\mathrm{pH}$ range $2.0-4.0)$, sodium acetate buffer $(100 \mathrm{mM}$ pH range $3.0-5.0)$, Tris-maleate buffer $(100 \mathrm{mM}$ $\mathrm{pH}$ 5.0-7.0) and Tris- $\mathrm{HCl}(100 \mathrm{mM} \mathrm{pH}$ range 7.0--8.0). The optimum temperature was determined at optimum $\mathrm{pH}$, in the temperature range of 20 $70^{\circ} \mathrm{C}$. The $\mathrm{pH}$ stability was investigated storing the enzyme diluted 5-fold for 24 $\mathrm{h}$ at room temperature in buffers with increasing $\mathrm{pHs}(2.0-8.0)$. The remaining activity was measured under standard conditions at optimum $\mathrm{pH}$ and temperature. The thermostability was studied by incubating the crude enzyme, withou substrate, for $1 \mathrm{~h}$, over a temperature range of $20-70^{\circ} \mathrm{C}$. The aliquots were assayed for residual activities at optimum conditions. Assays were done in triplicate. Enzymatic activity was calculated from the amount of reducing sugars released, using the DNS method.

\section{Effect of ethanol on invertase activity}

Increasing concentrations of ethanol from 0 to $20 \%, \mathrm{v} / \mathrm{v})$ were added to the reaction mixture to check their effects on invertase activity. Assays were carried out under optimal conditions of $\mathrm{pH} /$ temperature and in triplicate. A maximum value of activity was considered in the reaction mixture without ethanol.

\section{RESULTS AND DISCUSSION}

\section{Invertase production}

Among all the yeast strains tested, Candida stellata (N5 strain) was the only strain able to present significant invertase activity, with peak of production after 48 hours of $\mathrm{SmF}$ of $7.8 \mathrm{U} / \mathrm{ml}$ of fermented broth (Figla) (Table 2). It was compared with the invertase production by a commercial Saccharomyces cerevisiae strain at the same conditions. However, it presented a lower invertase activity $(2.5 \mathrm{U} / \mathrm{ml})$ (Figla). Other authors showed higher invertase activity for Saccharomyces cerevisiae. A value of $8.35 \mathrm{U} / \mathrm{ml}$ of invertase was obtained by Shafic et al. (2003). This result suggests $C$. stellata N5 strain is a good producer of this enzyme in short time (48 hours). At optimal conditions, $10.6 \mathrm{U} / \mathrm{ml}$ of activity were produced. Lower invertase activity values were found for other nonSaccharomyces yeast strains (Rubio et al. 2002; Caputo et al. 2012).
Table 2 Invertase production by $\mathrm{SmF}$ by yeast strains investigated in this study.

\begin{tabular}{|c|c|c|c|}
\hline Yeast species & Strain & $\begin{array}{c}\text { Peak of } \\
\text { activity (h) }\end{array}$ & $\begin{array}{c}\text { Maximum invertase } \\
\text { activity }(\mathrm{U} / \mathrm{ml})\end{array}$ \\
\hline $\begin{array}{l}\text { Hanseniaspora } \\
\text { uvarum }\end{array}$ & U6 & - & ND* \\
\hline $\begin{array}{l}\text { Hanseniaspora } \\
\text { uvarum }\end{array}$ & U17 & - & ND \\
\hline $\begin{array}{l}\text { Hanseniaspora } \\
\text { uvarum }\end{array}$ & N1 & - & ND \\
\hline $\begin{array}{l}\text { Hanseniaspora } \\
\text { uvarum }\end{array}$ & N7 & - & ND \\
\hline $\begin{array}{l}\text { Hanseniaspora } \\
\text { uvarum }\end{array}$ & N36 & - & ND \\
\hline $\begin{array}{l}\text { Hanseniaspora } \\
\text { uvarum }\end{array}$ & $10 \mathrm{~A}$ & - & ND \\
\hline $\begin{array}{l}\text { Hanseniaspora } \\
\text { uvarum }\end{array}$ & $3 \mathrm{~A}$ & - & ND \\
\hline $\begin{array}{l}\text { Saccharomyces } \\
\text { cerevisae }\end{array}$ & $\mathrm{N} 24$ & 48 & 2.5 \\
\hline $\begin{array}{l}\text { Saccharomyces } \\
\text { cerevisae }\end{array}$ & N37 & 48 & 2.8 \\
\hline $\begin{array}{l}\text { Saccharomyces } \\
\text { cerevisae }\end{array}$ & N38 & 48 & 2.6 \\
\hline $\begin{array}{l}\text { Saccharomyces } \\
\text { cerevisae }\end{array}$ & 3 & 48 & 2.3 \\
\hline Candida quercitrusa & N17 & 48 & 0.4 \\
\hline Candida quercitrusa & N19 & 48 & 0.7 \\
\hline Pichia orientalis & $\mathrm{N} 40$ & 48 & 1.2 \\
\hline Pichia orientalis & 52 & 48 & 1.0 \\
\hline Pichia orientalis & 18 & 48 & 1.0 \\
\hline Pichia orientalis & 28 & 48 & 0.9 \\
\hline Pichia kluyveri & $\mathrm{N} 31$ & - & ND \\
\hline Pichia terricola & $22 \mathrm{~A}$ & - & ND \\
\hline Pichia terricola & $5 \mathrm{~A}$ & - & ND \\
\hline Pichia occidentalis & 39 & 48 & 1.3 \\
\hline Pichia occidentalis & 41 & 48 & 1.5 \\
\hline Pichia occidentalis & 43 & 48 & 1.2 \\
\hline $\begin{array}{l}\text { Sporidiobolus } \\
\text { pararoseus }\end{array}$ & $8 \mathrm{~A}$ & - & ND \\
\hline Candida stellate & N5 & 48 & 7.8 \\
\hline Candida stellate & N9 & 48 & 7.3 \\
\hline $\begin{array}{l}\text { Aureobasidium } \\
\text { pullulans }\end{array}$ & $1 \mathrm{~A}$ & - & ND \\
\hline $\begin{array}{l}\text { Aureobasidium } \\
\text { pullulans }\end{array}$ & $4 \mathrm{~A}$ & - & ND \\
\hline $\begin{array}{l}\text { Aureobasidium } \\
\text { pullulans }\end{array}$ & $12 \mathrm{~A}$ & - & ND \\
\hline Cryptococcus laurenti & $\mathrm{U} 2$ & - & ND \\
\hline $\begin{array}{l}\text { Cryptococcus } \\
\text { flavescens }\end{array}$ & U8 & - & ND \\
\hline $\begin{array}{l}\text { Cryptococcus } \\
\text { flavescens }\end{array}$ & U10 & - & ND \\
\hline $\begin{array}{l}\text { Meyerozyma } \\
\text { quilliermondii }\end{array}$ & U5 & - & ND \\
\hline $\begin{array}{l}\text { Meyerozyma } \\
\text { quilliermondii }\end{array}$ & U9 & - & ND \\
\hline
\end{tabular}

*ND: not detected at fermentation broth.

After counting the viable cell number, it was observed that the peak of cellular multiplication for $C$. stellata $\mathrm{N} 5$ strain was up to $48 \mathrm{~h}$ ( $\log$ stage), followed by a stationary stage (between 48 and 96 hours of fermentation) and a decline stage (96 to 120 h) (Figure 1b). After 96 hours of fermentation, a small increase of the cell viability was once more observed. This oscillating behavior can probably be due to some experimental error or also by enzyme competition or other reasons. Nevertheless, this small variation is irrelevant since the peak of maximum growth and maximum enzyme production was at $48 \mathrm{~h}$, and, afterwards, both growth and enzyme production have decreased, with a low oscilation at 96 hours.

In this study, the number of viable cells between N5 strain and the commercial strain was also compared. Thus, it was observed that the cellular viability in $C$. stellata was six fold higher than in S. cerevisae (Table 3) at the analyzed conditions. 
Table 3 Cell viability among C. stellata and S. cerevisiae during SbmF.

\begin{tabular}{lccc}
\hline $\begin{array}{l}\text { Time } \\
\text { (hours })\end{array}$ & $\begin{array}{c}\text { Viability } C . \\
\text { stellata } \\
\left(* 10^{7} \text { cells } / \mathrm{ml}\right)\end{array}$ & $\begin{array}{c}\text { Viability } S . \\
\text { cerevisiae } \\
\left(* 10^{7} \text { cells/ml }\right)\end{array}$ & $\begin{array}{c}\text { Viability } \text { C. stellata/ } S . \\
\text { cerevisiae } \\
\left(* 10^{7} \text { cells } / \mathrm{ml}\right)\end{array}$ \\
\hline 0 & 1 & 1 & 1 \\
24 & 8 & 3 & 2.67 \\
48 & 22 & 2 & 14 \\
72 & 14 & 3.5 & 4 \\
96 & 17.5 & 3.2 & 5.468 \\
120 & 12 & 2.8 & 4.285 \\
Average & & & 6.08 \\
\hline
\end{tabular}

As far as it concerns the $\mathrm{pH}$ of the medium during the fermentation, the $\mathrm{pH}$ of $C$ stellata medium remained acidic during the whole process, being advantageous to yeast growth (Fig 1c). In contrast, the $\mathrm{pH}$ of the medium inoculated with the commercial strain increased, reaching a $\mathrm{pH}$ range of 6.0 to 8.0 during the fermentation. These $\mathrm{pH}$ values are not appropriate for yeast growth which can justify the lower invertase biosynthesis by this strain. In addition, basic $\mathrm{pHs}$ are favorable for most of the bacteria development which can spoil the fermentation broth. These results indicated that $C$. stellata N5 strain showed a better capacity to grow in a fermentation broth containing sucrose as the sole carbon source, suggesting it as promising yeast for application in food industries.

\section{Effects of $\mathrm{pH}$ and temperature}

The highest invertase activity was observed at pH 3.0 (Fig 2a). Andjelkovic et al. (2010) observed an optimum $\mathrm{pH}$ around 3.5 for an extracelular invertase produced by $S$. cerevisiae and Alegre et al. (2009) described extra and intracellular invertases of Aspergillus caespitosus with maximum activities at the $\mathrm{pH}$ range of 4.0-6.0. This result is interesting for application of this invertase in food industries, for example extraction of sugars for juice fabrication since the most of the fruits rich in sucrose exhibit acid $\mathrm{pHs}$, such as pineapple, peaches, apricots, organges, grapefruits and many others (Anon, 1962). Optimal temperature was achieved at $55^{\circ} \mathrm{C}(10.6 \mathrm{U} / \mathrm{ml}$ at optimal conditions) (Fig 2b). This result is in accordance with previous studies which described yeast invertases with optimal activity around $50-55^{\circ} \mathrm{C}$ (Kulshrestha et al., 2013 Valério et al., 2013).

The enzyme was stable in a broad range of $\mathrm{pH}(2.0$ to 8.0) (Fig 2c) and temperatures $\left(20-55^{\circ} \mathrm{C}\right)(\mathrm{Fig} 2 \mathrm{~d})$. It was stable under low temperatures, retaining around $95 \%$ of residual activity after incubation for $1 \mathrm{~h}$ at $20^{\circ} \mathrm{C}$ and up to $55^{\circ} \mathrm{C}$ (with a residual activity of $83 \%$ at this temperature. These results agreed with previous reports, which showed invertases with similar stabilities up to $55^{\circ} \mathrm{C}$ (Kulshrestha et al., 2013).
(A)

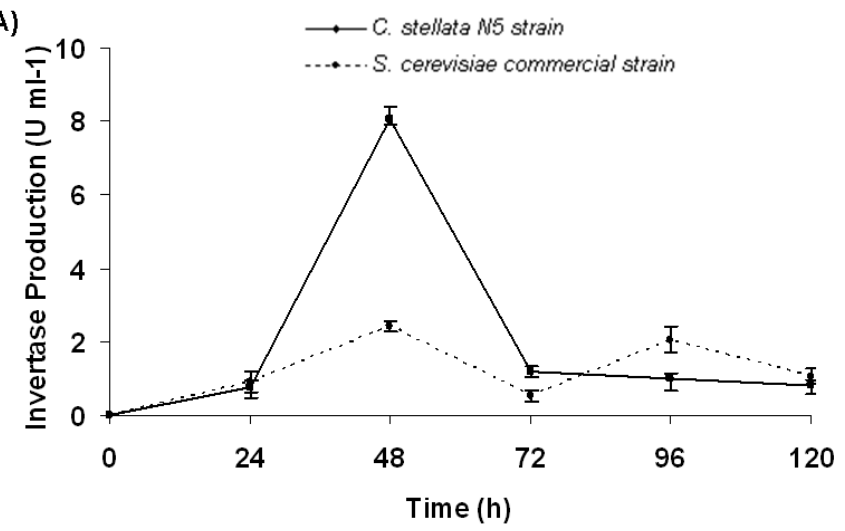

(B)

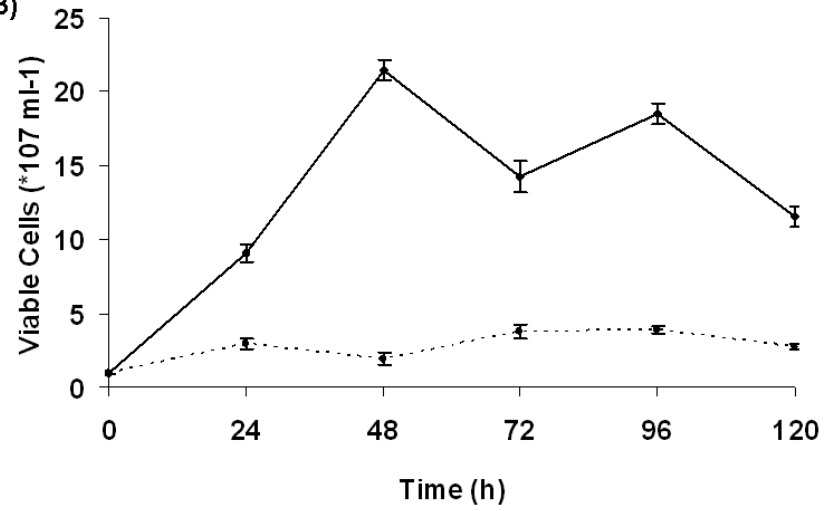

(C)

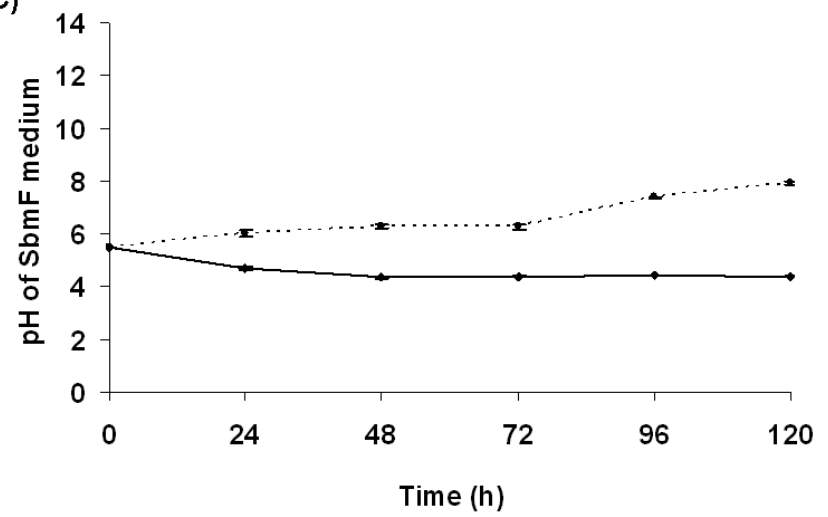

Figure 1 Comparison of the invertase biosynthesis (a), cell viability (b) and $\mathrm{pH}$ of fermentation media (c) among C. stellata and S. cerevisiae, during SbmF. Invertase activity expressed as $\mathrm{U} \mathrm{ml}^{-1}$; cell viability expressed in number of viable cells x $10^{7} \mathrm{ml}^{-1}$. Results are mean values from duplicate experiments (error bars indicate standard deviation $(P<0.05)$

\section{Ethanol effect}

The $C$. stellata's invertase was tolerant at low concentrations of ethanol, remaining $84.0,63.0$ and $58.0 \%$ of its original activity at $2.5,5.0$ and $7.5 \%$ of ethanol (w/v), respectively (Figure 3 ). However, at high concentrations of this alcohol, the activity was meaningfully reduced. This moderate tolerance to ethanol suggests that this invertase could also be suitable for application in the initial steps of alcoholic fermentation in ethanol production processes. These data indicate that the enzyme could be added at the beginning of alcoholic fermentation because at this stage low concentrations of ethanol are found, being useful to the increase of the amount of reducing sugars (Baffi et al. 2011). At industrial conditions, the maximum ethanol production achieves usually among $10-14 \%(\mathrm{v} / \mathrm{v})$ at the end of fermentation (Bai et al. 2008). 
(A)
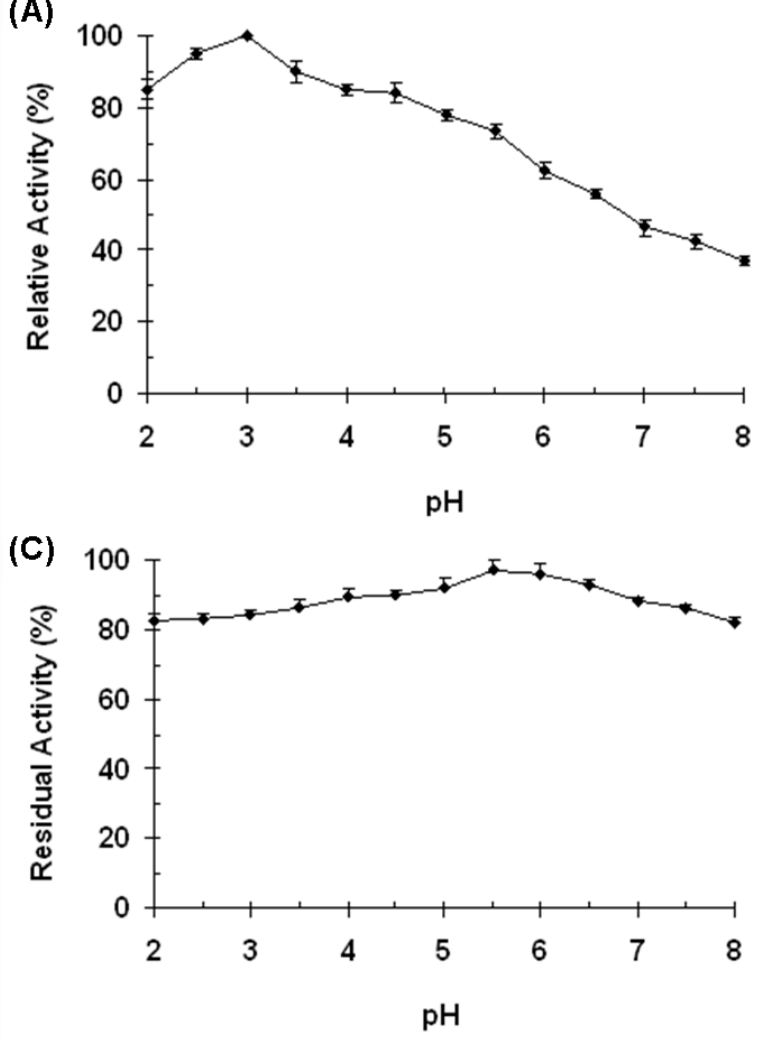

(B)

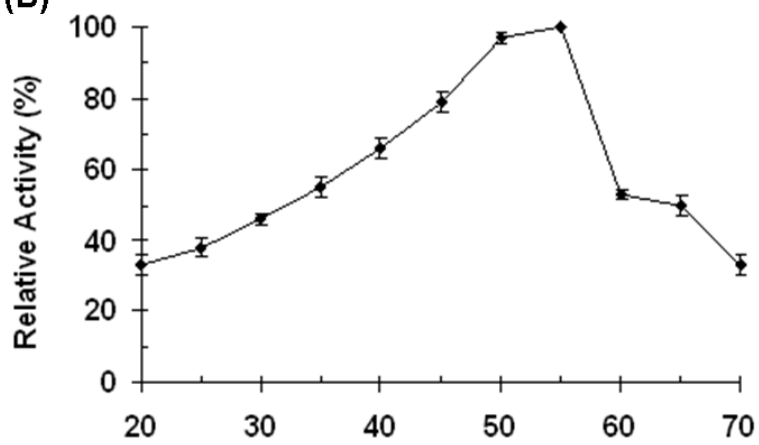

Temperature $\left({ }^{\circ} \mathrm{C}\right)$

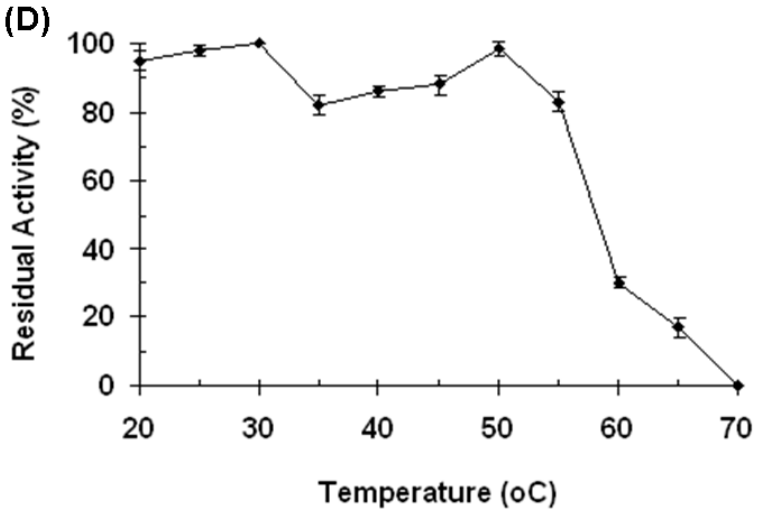

Figure 2 Effects of $\mathrm{pH}$ and temperature on $C$. stellata invertase. (a) Optimum $\mathrm{pH}$; (b) Optimum temperature; (c) pH stability and (d) thermostability. Results are mean values from duplicate experiments and error bars indicate standard deviation $(P<0.05)$

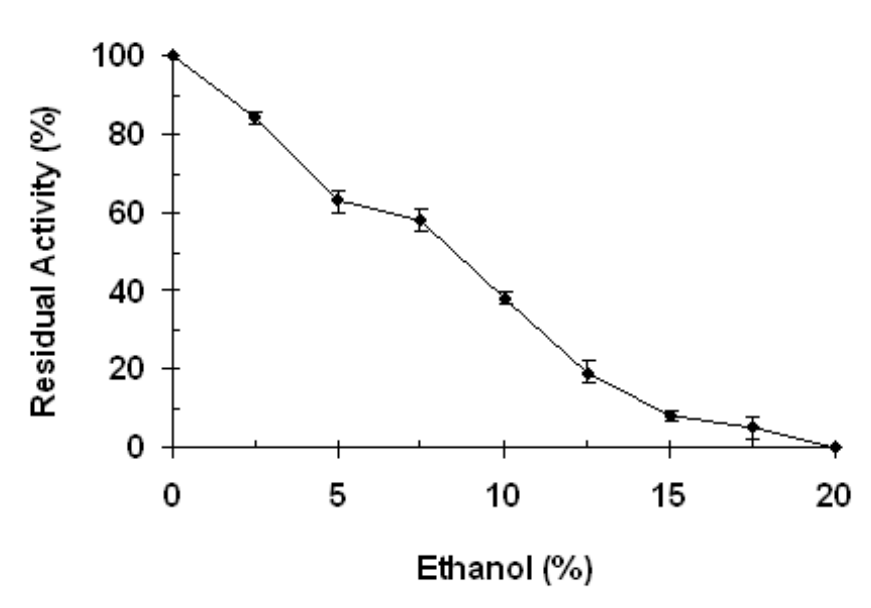

Figure 3 Effect of ethanol on the activity of $C$. stellata invertase. Results are mean values from duplicates and error bars indicate standard deviation $(P<0.05)$

\section{CONCLUSION}

This work showed evidence that $C$. stellata N5 strain is a potential producer of invertase. The results demonstrated that the enzyme was active and stable in a broad range of $\mathrm{pH}$ and temperatures and at low concentrations of ethanol. These data support this new invertase as a promising catalytic agent for use in several biotechnological processes in the food industry and alcoholic fermentations.

Acknowledgments: Financial support for carrying out this study provided by FAPESP and CNPq (Brazil) is properly acknowledged. C.A. Gargel thanks to CNPq for Master's scholarship and M.A. Baffi is grateful to FAPESP for PostDoctoral fellowship.

\section{REFERENCES}

ACOSTA, N., BELDARRAÍN, A., RODRÍGUEZ, L., ALONSO, Y. 2000. Characterization of recombinant invertase expressed in methylotrophic yeasts. Biotech. Appl. Biochem., 32, 179-187. http://dx.doi.org/10.1042/ba20000064 ALEGRE, A.C.P., POLIZELI, M.L.T.M., TERENZI, H.F., JORGE, J.A., GUIMARÃES, L.H.S. 2009. Production of thermostable invertases by
Aspergillus caespitosus under submerged or solid state fermentation using agroindustrial residues as carbon source. Braz J Microbiol 40, 612-622. http://dx.doi.org/10.1590/s1517-83822009000300025

ANDJELKOVIC, U., PIĆURIĆ, S., VUJČIĆ, Z. 2010. Purification and characterization of Saccharomyces cerevisiae external invertase isoforms. Food Chem, 120, 799-804. http://dx.doi.org/10.1016/j.foodchem.2009.11.013

ANON. 1962. pH Values of food products. Food Eng, 34(3), 98-99.

BAFFI, M.A., BEZERRA, C.S., ARÉVALO-VILLENA, M., BRIONES-PÉREZ A.I., GOMES, E., DA-SILVA, R. 2011a. Isolation and molecular identification of wine yeasts from a Brazilian vineyard. Ann Microbiol, 61, $75-78$ http://dx.doi.org/10.1007/s13213-010-0099-z

BAFFI, M.A., TOBAL, T., LAGO, J.H.G., LEITE, R.S.R., BOSCOLO, M., GOMES, E. AND DA-SILVA, R. 2011b. A Novel $\beta$-Glucosidase from Sporidiobolus pararoseus: Characterization and Application in Winemaking. $J$ Food Sci, 76, 997-1002. http://dx.doi.org/10.1111/j.1750-3841.2011.02293.x

BAI, F.W., ANDERSON, W.A., MOO-YOUNG, M. 2008. Ethanol fermentation technologies from sugar and starch feedstocks. Biotechnol Adv, 26, 89-105. http://dx.doi.org/10.1016/j.biotechadv.2007.09.002

BELCARZ, A., GINALSKA, G., LOBARZEWSKI, J., PENEL, C. 2002. The novel non-glycosylated invertase from Candida utilis (the properties and the conditions of production and purification). Biochim Biophys Acta, 1594, 40-53 http://dx.doi.org/10.1016/s0167-4838(01)00279-5

CAPUTO, L., QUINTIERI, L., BARUZZI, F., BORCAKLI, M., MOREA, M. 2012. Molecular and phenotypic characterization of Pichia fermentans strains found among Boza yeasts. Food Res Int, 48, 755-762. http://dx.doi.org/10.1016/j.foodres.2012.06.022

CHELLIAPPAN, B., MADHANASUNDARESWARI, K. 2013/14. Production and optimization of growth conditions for invertase enzyme by Aspergillus sp., in solid state fermentation (SSF) using papaya peel as substrate. J Microbiol Biotechnol Food Sci, 3(3), 266-269.

DE ALMEIDA, A.C.S., DE ARAÚJO, L.C., COSTA, A.M., DE ABREU, C.A.M., LIMA, M.A.G.A., PALHA, M.L.A.F. 2005. Sucrose hydrolysis catalyzed by auto-immobilized invertase into intact cells of Cladosporium cladosporioides. Electron J Biotechnol, 8, 54-62. http://dx.doi.org/10.2225/vol8issue 1-fulltext-11

HUSSAIN, A., RASHID, M.H., PERVEEN, R., ASHRAF, M. 2009 Purification, kinetic and thermodynamic characterization of soluble acid invertase from sugarcane (Saccharum officinarum L.) Plant Phys Biochem, 47(3), 188-194. http://dx.doi.org/10.1016/i.plaphy.2008.11.001

KARWOSKI, M., VENELAMPI, Z., LINKO, P., MATTILA-SANDHOLM, T. 1995. A staining procedure for viability assessment of starter culture cells. Food Microbiol, 12, 21-29. http://dx.doi.org/10.1016/s0740-0020(95)80075-1 
KULSHRESTHA, S., TYAGI, P., SINDHI, V., YADAVILLI, K.S. 2013 Invertase and its applications - A brief review. J Pharm Res, 7(9), 792-797. http://dx.doi.org/10.1016/j.jopr.2013.07.014

LEE, W.C., HUANG, C.T. 2000. Modelling of ethanol production using Zymomonas mobilis ATCC 10988 grown on the media containing glucose and fructose. Biochem Engineer J, 4, 217-227. http://dx.doi.org/10.1016/s1369. 703x(99)00051-0

MILLER, G.L. 1959. Use of dinitrosalicylic acid reagent for determination of reducing sugar. Anal Chem, 31, 426-429. http://dx.doi.org/10.1021/ac60147a030 NAKANO, H., MURUKAMI, H., SHIZUMA, M., KISO, T., DE ARAUJI, T.L., KITAHATA, S. 2000. Transfructosylation of thiol group by beta-fructo $\begin{array}{llll}\text { furanosidases. Biosci } & \text { Biotechnol, } & \text { 64(7), } & \text { 1472-1476 }\end{array}$ http://dx.doi.org/10.1271/bbb.64.1472

PATARO, C., GUERRA, J.B., GOMES, F.C.O., NEVES, M.J., PIMENTEL, P.F., ROSA, C.A. 2002. Trehalose accumulation, invertase activity and physiological characteristics of yeasts isolated from $24 \mathrm{~h}$ fermentative cycles during the production of artisanal Brazilian cachaça. Braz J Microbiol, 33, 202208. http://dx.doi.org/10.1590/s1517-83822002000300003

RUBIO, M.C., RUNCO, R., NAVARRO, A.R. 2002. Invertase from a strain of Rhodotorula glutinis. Phytochem, 61, 605-609. http://dx.doi.org/10.1016/s00319422(02)00336-9

SHAFIQ, K., SIKANDER, A., UL-HAQ, I. 2003. Time course study for yeast invertase production by submerged fermentation. J Biol Sci, 3(11), 984-988. http://dx.doi.org/10.3923/jbs.2003.984.988

TÜRKEL, S., TURGUT, T., KAYAKENT, N. 2006. Effect of osmotic stress on the derepression of invertase synthesis in nonconventional yeasts. Lett Appl Microbiol, 42(1), 78-82. http://dx.doi.org/10.1111/j.1472-765x.2005.01806.x

UMA, C., GOMATHI, D., RAVIKUMAR, G., KALAISELVI, M., PALANISWAMY, M. 2012. Production and properties of invertase from a Cladosporium cladosporioides in SmF using pomegranate peel waste as substrate. Asian Pac J Trop Biomed, S605-S611. http://dx.doi.org/10.1016/s2221-1691(12)60282-2

VALÉRIO, S.G., ALVES, J.S., KLEIN, M.P., RODRIGUES, R.C., HERTZ, P.F. 2013. High operational stability of invertase from Saccharomyces cerevisiae immobilized on chitosan nanoparticles. Carbohydr Polym, 92, 462- 468. http://dx.doi.org/10.1016/j.carbpol.2012.09.001 